\title{
Development of Web-Based Learning Media on Social Studies Subject at Junior High School Methodist Lubuk Pakam, Indonesia
}

\author{
Emelda Thesalonika ${ }^{1}$, Samsidar Tanjung ${ }^{2}$, Restu $^{2}$, Effendi Manalu ${ }^{2}$ \\ ${ }^{I}$ Master Student in State University of Medan (Unimed), Medan, Indonesia \\ ${ }^{2}$ Lecturer in in State University of Medan (Unimed), Medan, Indonesia \\ lonika12thesa@gmail.com
}

\begin{abstract}
Prioritizing WEB-based knowledge learning. The approach taken to familiarize students with high-level thinking is helped by WEB. Based on preliminary analysis, it is known that teachers have difficulties in designing a WEB-based social science learning media. This study uses the ADDIE model to develop web-based learning media. The development research flow, namely, analysis, design, development, implementation, and evaluation. The results of research in the form of WEB-based social studies learning media products have been declared feasible by a team of experts. Practically, this research can be useful for teachers, the government.
\end{abstract}

Keywords: learning media; social sciences; WEB

\section{Introduction}

The development of technology has a great influence in the field of education. Especially on internet technology, it provides opportunities and helps teachers to convey subject matter when learning activities take place. The influence of this development is evident in the efforts for renewal of the education and learning system (Kuswanto 2017). The use of multimedia contained in internet technologies such as audio, video, images, and animation can help students understand complex knowledge (Mayer 2005). Internet technology is referred to as "a cognitive tool that changes, adds to, and supports engagement among learners" so that this technology has a significant influence on the curriculum, teaching methodology, and learning process (Kinuthia 2006, Rhema 2010).

Learning is a process, way and actions that affect students how to learn (Kurniasih 2016). Web-based learning can support constructivism-oriented pedagogical approaches such as social learning by providing an environment and technology that promotes and encourages this interaction. The learning objectives of social science are, provide knowledge, develop critical thinking skills and inquiry, practice independent learning, develop intelligence, habits and social skills, live moral values, develop awareness and care for the community and the environment (Supardi 2011). Recently web-based learning has become an integral part of the social dimension of learning, this is seen from the goal of WEB-based learning to provide and maintain a friendly and interactive environment so that students feel safe and comfortable and can interact with each other while learning (Moallem 2003 , Anderson 2004).

This study aims to develop WEB-based social studies learning media which must be declared feasible by a team of experts and program professionals must be declared worthy of small groups and large groups.

\section{Review of Literature}

\subsection{Media}

Media means middle, intermediary or delivery means an intermediary or delivery message from the sender to the recipient of the message. Learning media in the broadest sense is "media not only covers complex electronic communication media, but also includes simple 
tools, such as slides, photography, diagrams, and charts made by teachers, real objects and outof-school visits (Hamalik, 2005). Based on this study, it was concluded that learning media were tools or materials that contained information. These tools or functions can be used as intermediaries in communicating with users. The purpose of learning media is to stimulate thoughts, feelings, attention and interests so that the delivery of information goes smoothly.

Media are forms of communication both printed and audivisual and its equipment (communication tools in the form of audivisual and printed). The media is an introduction to the message from the sender to the message recipient, thus the media is a vehicle for channeling learning information or channeling the message (Rusman et al. 2013). Media should be able to be manipulated, can be seen, heard and read (Sadiaman et al. 2012). Media are all forms and channels that are used to channel messages or information (Hamzah, 2011). It serves to stimulate thoughts, feelings, concerns, and interests that can motivate students to better understand the material.

Based on the above opinion it can be concluded that the media is a tool to support learning to run smoothly and get good learning outcomes. Media can be interpreted as a liaison or intermediary between the parties between the giver and receiver of information. The use of media as a liaison between teachers and students is called learning. This makes learning requires media support to deliver the material to be learned by students.

Experience directly gives a meaningful impression about the information and ideas contained in the experience. This is because it involves the sense of seeing, listening, taste, smell, and touch. Another term is learning by doing, for example taking part in preparing food, making skills, doing practice in the labotarium, and others.

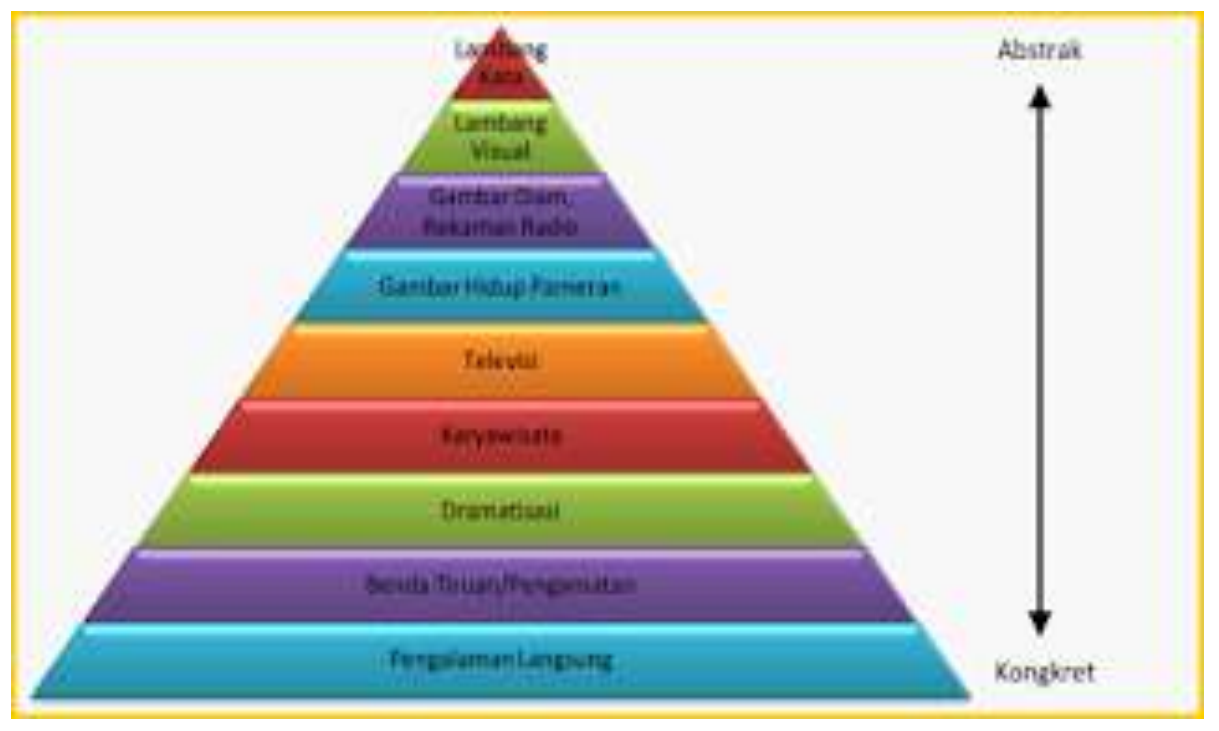

Figure 1. Cone Edgar Dale Experience

If it is seen from the clutter, that the level of tab will message / information will be typed in a slow pace like chart, graphic, or word. If the content is contained in a symbol, the senses used to interpret all of the senses are visually perceiving and hearing, whereas the involvement of the imagination is increasingly developing even though physical disabilities are lacking (Arsyad, 2013). Concrete experiences and extracts in natural experiences have changed. Direct experience changes and extends the reach of the extraction of people, while the ability to 
interpret words slowly helps to understand the experience in which a person is involved directly.

\subsection{Social Media Learning Media Web-based}

The media are classified according to the size and complexity of the tools and equipment of several groups, namely media without two-dimensional projection, television, video, and computer (Lestari, 2018). Based on an understanding of the classification of media learning media, it will be easier for teachers or other practitioners in making appropriate media selection when planning learning to achieve certain goals. The selection of media that is tailored to the objectives, materials, and abilities and characteristics of students, will greatly support the efficiency and effectiveness of the learning process and outcomes.

Types of social studies learning media are all media that is certainly in accordance with the subject material. Learning that uses contextual-based media will make students learn more meaningfully (Sulfiah, 2016). Learning media in social studies are not only teaching aids, but the surrounding environment is also a media in social studies learning with pre-literacy material.

The ideal social media learning media must be adapted to the concepts in social studies learning. According to Gagne (in Jayanti, 2013) the concept is divided into two categories, namely the concept of concept and the concept of undefined (abstract).

The concept of concrete is an idea that is derived from the object of the creature or concretely events. Examples of the concept of concrete, namely chili grinding from stone, jewelry, human groups and so forth. Apart from that, a well-defined concept (abstract concept) is an abstraction or idea that can be derived from abstract objects. Examples from the abstract, namely the theory of Darwin Darwin, the theory of the spread of early humans, and so forth.

\subsection{Social Sciences Learning (IPS)}

Social Sciences is one of the subjects that combines social and humanities disciplines. Trianto (2010), argues that IPS is an integration of various branches of social sciences, such as sociology, history, geography, economics, politics, law and culture. Social Sciences are formulated on the basis of reality and social phenomena that are manifested in an interdisciplinary approach from the aspects and branches of social science. Social studies is part of the school curriculum that is derived from the contents of branches of social science.

Regulation of the Minister of National Education of the Republic of Indonesia Number 22 of 2006 concerning Content Standards for primary and secondary education contains about Social Sciences Education as one of the subjects that are given starting from SD / MI / SDLB to SMP / MTS / SMPLB. However Somantri (2001) also argues that social studies education for the school level is a simplification of the disciplines of the social sciences, psychology, philosophy, state ideology and religion which are organized and presented scientifically and psychologically for educational purposes.

The meanings of IPS according to the National Council for Social Studies (NCSS) in Supardi (2011: 182) are:

"Social studies are the integrated study of the social sciences and humanities to promote civic competence. Within the school program, social studies provides coordinated, systematic study drawing upon such disciplines as antropology, archeology, economics, geography, history, law, philosophy, political science, psychology, religion, and sociology, as well as appropriate content drom the humanities, mathematics, and the natural sciences." 


\subsection{WEB}

According to the Wahana Komputer Research and Development Team (2004: 6), explained that the website is a place in the World Wide Web where the homepage of an organization or individual is located. A website (website) is usually placed at least on a web server that can be accessed through a network such as the internet, or a local area network (LAN) through an internet address that is recognized as a Uniform Resource Locator (URL).

Domain is considered to be closely related to regional understanding, authority. An organizational unit with administrative responsibilities for naming networks or hosts. Unique name to ensure the address on a web page on the internet. This domain consists of 2 or more parts separated by dots. For example mail.yahoo.com, and www.hotmail.com. Hosting comes from the word host. Computers that are connected in a network. Utilizing the facilities available in a computer connected to the network. Internet service for placing information on web pages, email storage, databases, etc. To put it simply, this service is a solution for placing your web pages online. Thus, we do not need to provide a special computer that is always online at the office or at home, but simply by working with this hosting service provider (http://www.quipperschool.portalguru.com).

The structure of the website page consists of headers, content and footers. Inside the header can be entered a logo, banner, motto or website name. In the content can be included all that will be displayed as the main topic of the website, while the footer can contain additional information or information that supports the website, it is necessary to support the elements of the domain name, home where the website (web hosting), language program (scripts program), website design, data transfer program to the data center.

\subsection{Development of Web-Based Media}

Information technology is an inseparable part of the millennial era. In line with the statement, "Web-based learning media can help increase students' motivation and reasoning abilities" Yususf, et al (2016). Millennial era students now use the internet more as part of their daily lives. Students are expected to understand the material on the subject of the use of information technology and prospects by using a material presentation in the form of text accompanied by pictures and videos.

Geography learning also needs to take advantage of information technology to increase student motivation in learning. The purpose of accessing the website is very diverse, for example finding information, downloading (downloading), communicating, watching videos, and what is popular right now is to socialize on social media networks. The web is no longer just a place to look for information but a place where people do various activities, just like in the real world; the web is a workplace and home for most people.

Web-based learning makes it easy for students to access the material so that it is easy to understand. In line with the opinion of Rusman (2013) that, "the five advantages of web-based learning, namely: access is available anytime, anywhere, around the globe (access is available anytime, anywhere, in the world around) ". the internet has become a very widely used twoway communication tool. Students have enormous access to any information including learning information at this time.

\subsection{Development of ADDIE Model}

Development research has procedures or steps to develop it. These steps are commonly referred to as development models. Each development model has differences. In line with the opinion of Syafiudin, et al (2016) which states that, "Each development model has 
characteristics that distinguish it from other models". Differences or characteristics of development models can be seen from the number and stages of steps.

The ADDIE model is a singular of Analysis, Design, Development or Production Implementation or Delivery and Evaluation. The product development steps in this research and development model are more rational and more complete than 4D. This model is used for various forms of product development such as models, learning strategies, learning methods, media and teaching materials. The ADDIE model was developed by Dick and Carey in 1996 to design learning systems. The following are some activities at each stage of developing a learning model or method.

\section{Analysis}

At this stage, the main activity is in analyzing the need to develop new learning models or methods as well as analyzing the feasibility and requirements for developing new models or methods. Development of new models or learning methods begins with problems in models or learning methods that have been applied. Problems can occur because the existing learning model or method is no longer relevant to the needs of the target, learning environment, technology, characteristics of students, and others.

\section{Design}

The design of the model or the method of learning, the Design stage has similarities with designing learning activities. This activity is a systematic process that starts from setting learning objectives, designing scenarios or learning activities, designing learning tools, designing learning materials, and evaluating learning outcomes. The design of this learning model or method is still conceptual and underlies the subsequent development process.

\section{Development}

Development in the ADDIE model contains product design realization activities. The design phase has been drafted a conceptual framework for the application of new learning models or methods. In the development stage, the conceptual framework is realized into a product that is ready to be implemented. For example, if the design stage has been designed to use new models or methods that are still conceptual, at the development stage a learning device is prepared or made with such new models or methods such as lesson plans, media, and learning materials.

\section{Implementation}

At this stage the product is implemented on the test subject. Implementation steps on the design and methods that have been developed in a real situation, namely class. During implementation, the design models or methods that have been developed are applied to the actual conditions. The material is delivered according to the new model or method developed. The method applied is complete, and then an initial evaluation is carried out to provide feedback on the application of the next model or method.

\section{Eveliation}

Evaluation is carried out in two forms, namely formative and summative evaluation. Formative evaluations are carried out at the end of each face-to-face (weekly), while summative evaluations are carried out after the activities end in whole (semester). Addictive evaluation measures the final competency of the subject or learning objectives to be achieved. The results of the evaluation are carried out to provide feedback to the users of the model or 
method. Revisions are made according to evaluation results or needs that cannot be met by the new model or method.

\section{Method}

The research was conducted in class VII of the Lubuk Pakam Methodist Private Middle School. Small group testing is done with 20 respondents (students), whereas for large group testing 30 respondents (students).

\section{Discussion}

Research on the development of social media learning based on WEB refers to efforts to produce research steps using the ADDIE model. The development of WEB-based learning media is based on analysis and study of literature on learning theories. Based on the study of literature there are three learning theories that form the basis of the development of instructional media, namely cognitive learning theory and constructivism learning theory. Based on the results of the field needs analysis interview, it is known that schools have implemented the 2013 curriculum, the use of instructional media in social studies subjects is limited to power point display, so that internet-based learning is underutilized. This results in students feeling bored with social studies learning.

The validation of the experts is carried out before the trial product of small groups and large groups. Validation of experts includes media, design and material experts. Based on the results of the questionnaire learning media expert assessment by media experts, it is known that the level of product loss reached $4.45 \%$.

\section{Graphic Assessment Aspect of WEB Media Feasibility}

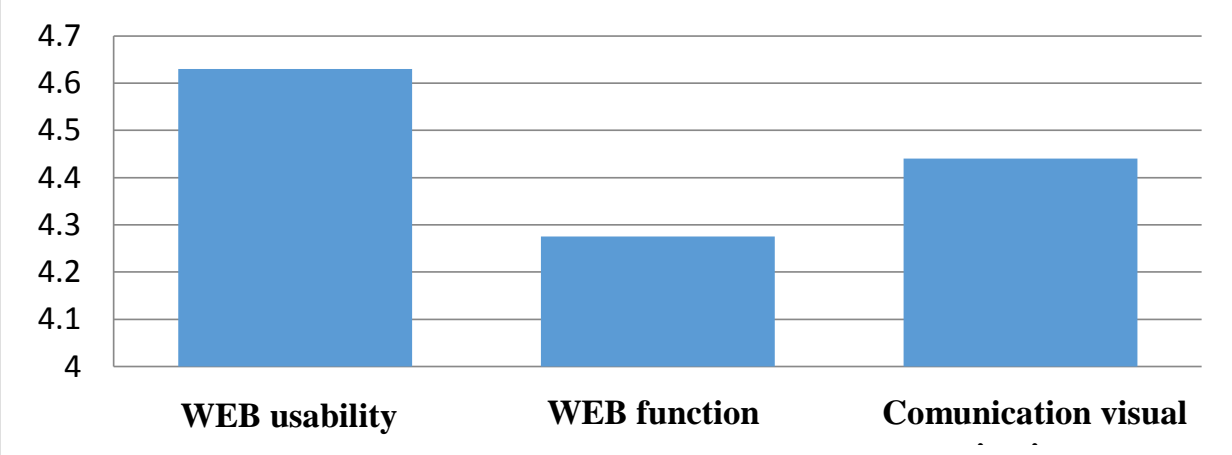

Figure 2. Media Expert Validation Results

The graph above is known to the development of Web-based social media learning media based on aspects of web usability this is declared valid with a percentage score of $4.63 \%$ with the criteria of "very good", then the aspect of web functions is declared valid with a percentage score of $4.28 \%$ with the criteria of "very good ", And the aspect of visual communication with a percentage of $4.44 \%$ with the criteria of" very good"

What needs to be validated in this research development is also media design. Based on the results of learning design expert validation shows the quality of learning design is valid 
with a percentage score of $4.00 \%$ with the criteria of "good", then the quality of the design of information is declared valid with a percentage score of $4.19 \%$ with the criteria of "very good", the quality of interaction with the percentage $4.38 \%$ with "very good" criteria, and percentage quality aspects with a percentage of $4.17 \%$.

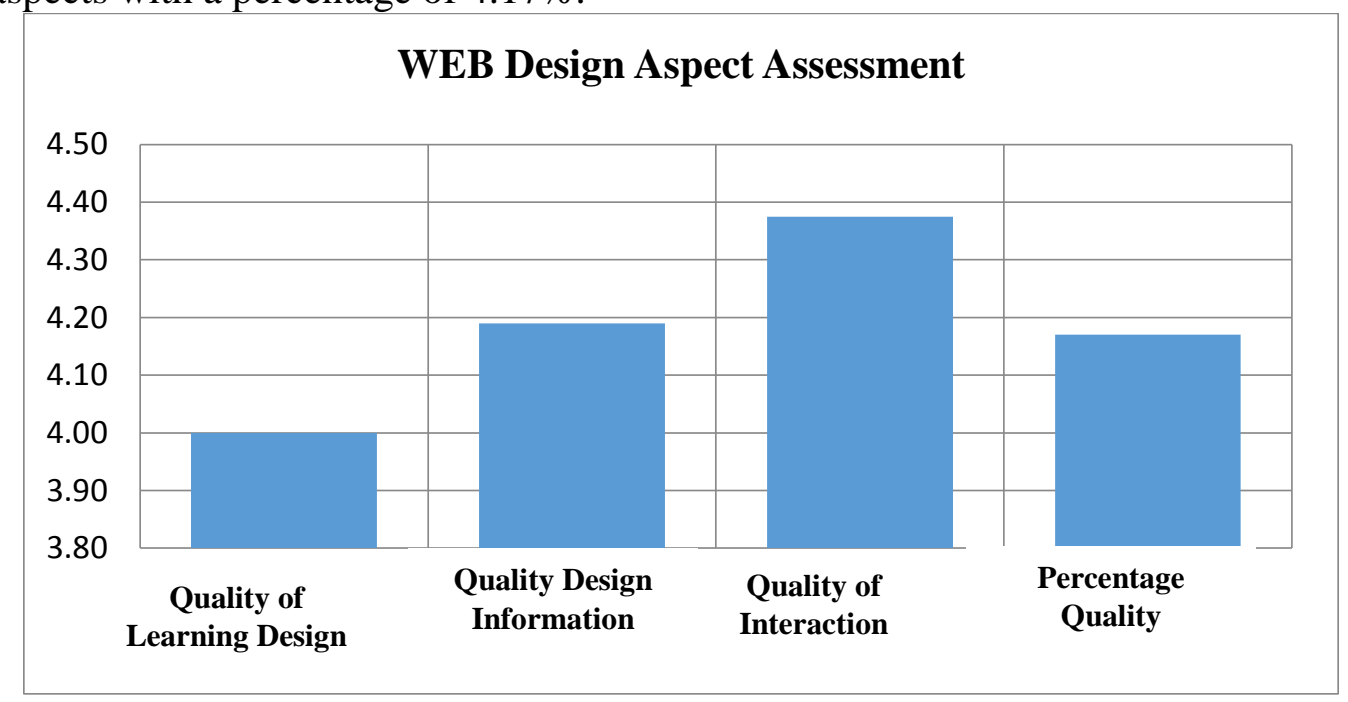

Figure 3. Design Expert Validation Results

Material validation was also carried out in the development of instructional media. Based on the results of the expert assessment of learning material on aspects of learning design declared valid with a percentage score of $4.17 \%$ with "very good" criteria, then on the content aspect of social studies learning material is valid with a percentage score of $4.32 \%$ with the criteria of "very good", and language and communication aspects with a percentage of $4.50 \%$ with "very good" criteria.

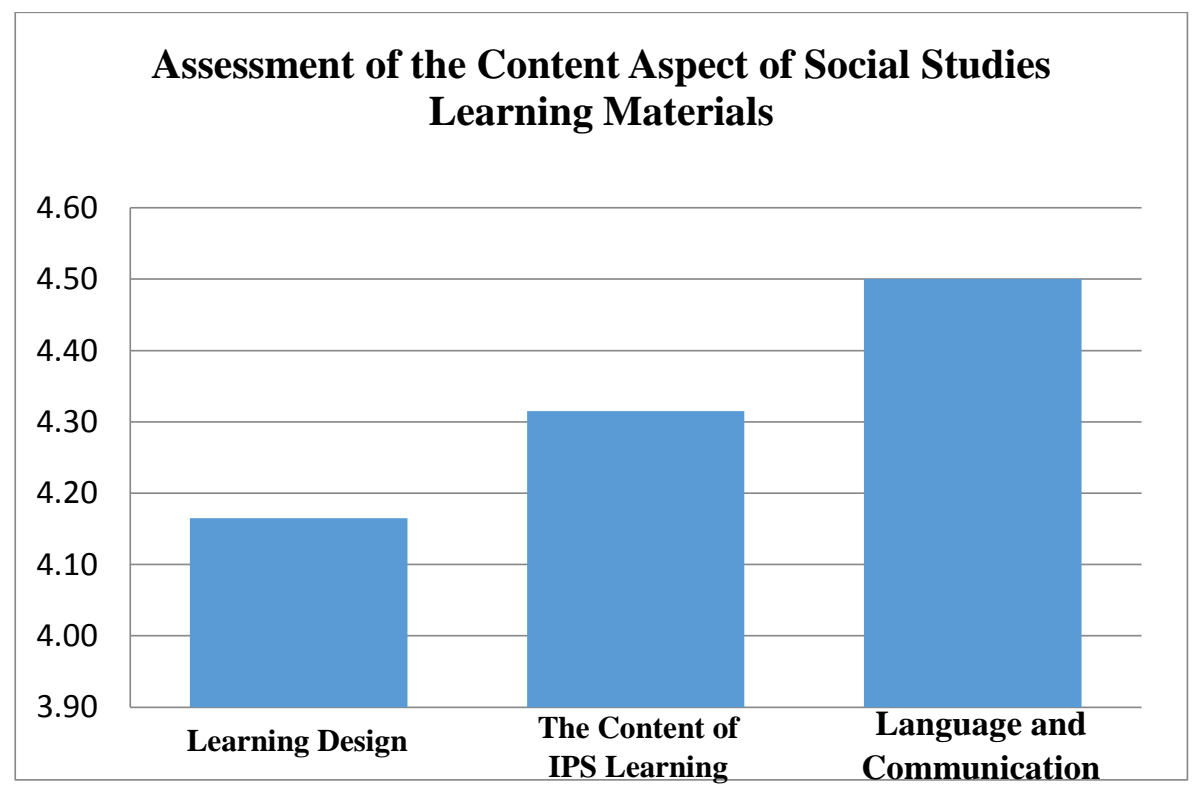

Figure 4. Expert Material Validation Results 
Overall, based on expert validation it is stated that the product is very good and appropriate based on material, design and media expertise. The development of Web-based social studies learning media is feasible for field trials.

The results of individual trials on students' perceptions of learning media using the web developed showed very good criteria with an average percentage of $92.94 \%$. The implementation of individual trials aims to find out the opinions of students as users before conducting small group trials. Students' perceptions consist of several categories of assessment indicators, namely aspects of content eligibility, presentation eligibility, language, and image selection.

Table 2. Percentage Acquisition Score Individual Trial Against Learning Media Using the Web

\begin{tabular}{clcc}
\hline No & Assessment Indicator & Average Percentage & Criteria \\
\hline 1 & Content eligibility aspects & $93,33 \%$ & Very good \\
\hline 2 & Presentation Aspect & $87,50 \%$ & Very good \\
\hline 3 & Linguistic Aspects & $95,83 \%$ & Very good \\
\hline 4 & Aspects of Image Selection & $100 \%$ & Very good \\
\hline & Average & $\mathbf{9 4 , 1 7 \%}$ & Very good \\
\hline
\end{tabular}

The results of the assessment of students' perceptions in small group trials stated that learning media using the developed web were stated with "very good" criteria with an average score of $94.17 \%$. In the small group trial phase which was stated to be very good, there was no need for revisions so that it could be continued in the field trials.

Table 3. Percentage Acquired Small Group Trial Score Against Learning Media Using the web

\begin{tabular}{cccc}
\hline No & Assessment Indicator & Average Percentage & Criteria \\
\hline 1 & Content eligibility aspects & $94,44 \%$ & Very good \\
\hline 2 & Presentation Aspect & $97,91 \%$ & Very good \\
\hline 3 & Linguistic Aspects & $95,45 \%$ & Very good \\
\hline 4 & Aspects of Image Selection & $95,83 \%$ & Very good \\
\hline & Average & $\mathbf{9 5 , 9 1 \%}$ & Very good
\end{tabular}

The limited field trial was conducted on 30 students of class VII of the Lubuk Pakam Methodist Private Middle School. In this trial the results of students' perceptions of learning media using the web have been developed having "very good" criteria with an average score of $95.91 \%$. The assessment of limited field trials is the final stage of testing the learning media products using the web in class VII. The results of this assessment concluded that the media developed received very cool responses like students as users of the product.

Table 4. Percentage Obtained Limited Field Trial Score Against Learning Media Using the web

\begin{tabular}{clcc}
\hline No & Assessment Indicator & Average Percentage & Criteria \\
\hline 1 & Content eligibility aspects & $93,33 \%$ & Very good \\
\hline 2 & Presentation Aspect & $87,50 \%$ & Very good \\
\hline 3 & Linguistic Aspects & $95,83 \%$ & Very good \\
\hline
\end{tabular}




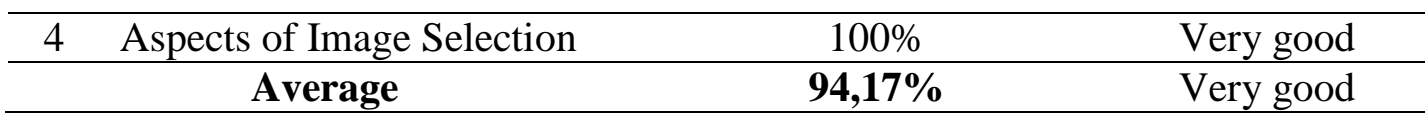

Based on the formulation of the problem and the questions raised in this study that is about the validity and effectiveness of web-based teaching materials on trials conducted on products, whether answered or not. The results of the analysis obtained from media experts, material experts, and design experts that the Web-based social studies learning media developed are valid and feasible to use.

Basically, social studies subjects are very close to life in this modern era. The difficulty of students in understanding social studies lessons is because the learning methods and media used by teachers are not creative. In the process of learning social science, there are still many teachers who are monotonous and less creative in using learning media, making students feel bored/bored, sleepy, not concentrated, and busy themselves. The role of the media as a communication tool is very important in carrying out the learning process because of the lack of use of media in explaining the material will make it difficult for students to build knowledge.

Social studies pre-asking material could once be applied in the form of learning media so that children can find their own experiences. This learning media is compiled using a web that has interactive animation capabilities, in addition it can import images and animations from other programs so that the resulting media is more interesting.

\section{Conclusion}

This results in research on the development of Web-based social media learning media products for pre-literate material that has been declared feasible by a team of experts and individual trials, small group trials and limited field trials. Web-based learning media are used to support complex student knowledge. The development of Web-based social studies learning media is very feasible as a learning medium for teachers and students.

\section{References}

Anderson, T. 2004. Teaching in an online learning context, in Anderson, T. and Elloumi, F. Athabasca: Athabasca University.

Arsyad, Azhar. 2013. Media Pembelajaran . Jakarta: PT. Raja Grafindo.

Hamzah, Nina. 2011. Teknologi Komunikasi \& Informasi Pembelajaran. Jakarta: PT. Bumi Aksara.

Herman, Dwi Sujono. 2008. Accessed Juni 24, 2019. https://eprints.uny.ac.id/6314/1/Modul_Pelatihan_Elearning_2008.pdf.

Kinuthia, W. and Dagada, R. 2006. "Elearning Delivery: Exploratory Study of ICT in Higher Education in South Africa." International Journal on E-Learning Vol. 7 No. 4, pp. 62339.

Kurniasih, Imas., \& Sani Berlin. 2016. Ragam Media Pembelajaran. Jakarta: Kata Pena.

Kuswanto, J., \&, Walusfa, Y. 2017. "Pengembangan Multimedia Pembelajaran pada Mata Pelajaran Teknologi Informasi dan Komunikasi Kelas VIII." Innovative Journal of Curriculum and Educational Technology (IJCET 58-64.

Mayer, R.E. 2005. Introduction to Multimedia Learning. New York: Cambridge University Press. 
Moallem, M. 2003. "An interactive online course: a collaborative design model." Educational Technology Research and Development Vol. 51 No. 4, pp. 85-103.

Rhema, A. and Miliszewska, I. 2010. "Towards e-learning in higher education in Libya." Issues in Informing Science and Information Technology, Vol. 7, pp. 423-7.

Rusman, Kurniawan. 2013. Pembelajaran Berbasis Teknologi Informasi dan Komunikasi. jakarta: PT. Raja Grafindo.

Sadimanan, Arif. 2006. Strategi Pembelajaran. Jakarta: PT. Raja Grafindo.

Sulfah, Umi., \& Sulisworo Dewi. 2016. "Pengembangan media pembelajaran Kontekstual Mengunakan Komik Fisika Untuk Peserta didik SMP/MTS Kelas VII Pada Pokok Bahasan Kalor." Jurnal Pendidikan Fisika.

Supardi. 2011. Dasar-dasar Ilmu Sosial. Yogyakarta: Ombak.

Supriadi. 2011. Strategi Belajar Mengajar. Yogyakarta: Cakrawala Ilmu.

Suwarti. 2012. Konsep Dasar IPS . Malang: Malang Perss.

Trianto. 2013. Model Pembelajaran Terpadu Konsep Strategi dan Implementasi dalam kurikulum Tingkat Satuan Pendidikan (KTSP).Jakarta: Bumi Aksara. 